\title{
THE EFFECTIVENESS OF COOPERATIVE LEARNING MODEL OF TEAM ASSISTED INDIVIDUALIZATION (TAI) TYPE AND STUDENT TEAMS ACHIEVEMENT DIVISIONS (STAD) TYPE TOWARD MATHEMATICS LEARNING OUTCOMES
}

\author{
Sharah Mita Sukmawatia, Widayatib \\ Program Studi Pendidikan Matematika Universitas Ahmad Dahlan \\ Jalan Ring Road Selatan, Tamanan, Banguntapan, Bantul Yogyakarta \\ acmdiansha@gmail.com, ${ }^{\mathrm{b}} \underline{\mathrm{umm}}$
}

\begin{abstract}
Learning in school is still dominated by the teacher, causing a lack of involvement of the student in participating in learning activities and have difficulty in understanding the material. This study aims to determine the effectiveness of the use of cooperative learning model type TAI and STAD on the results of student's mathematics learning in class VIII SMP Negeri 1 Kretek Bantul Academic Year 2015/2016. The population in this study were all students of class VIII SMP Negeri 1 Kretek Bantul consists of 6 classes. The sampling technique using random sampling techniques, derived class VIII B as the experimental class I (TAI), VIII D as the experimental class II (STAD), and VIII C as the control class. Designs in this study using Posttest-Only Control Design. The data collection technique using the test method. Instrument test using validity test and reliability test. Test requirements analysis includes tests of normality and homogeneity test. Analysis of data to test the hypothesis using analysis of variance and LSD test. Results of analysis of variance with a significance level of $5 \%$ and $\mathrm{df}=(2,79)$ show that: (1) there is a difference between the results of the students' mathematics learning using learning model type TAI, STAD learning model, with the conventional learning models. This is indicated by the value and $F_{\text {count }}=9,4784$ and $F_{\text {table }}=3,125, F_{\text {count }}>F_{\text {table }}$ then $H_{0}$ rejected and (2) learning model type TAI and STAD more effective than conventional learning models on the results of students' mathematics learning. This is indicated by the results of LSD in case I $\left|\bar{y}_{1}-\bar{y}_{2}\right|=8,83$ and LSD $=8,84$, consequently $\left|\bar{y}_{1}-\bar{y}_{2}\right|<L S D$ so $H_{0}$ accepted. In Case II $\left|\bar{y}_{1}-\bar{y}_{3}\right|=17,17$ and LSD $=8,76$, consequently $\left|\bar{y}_{1}-\bar{y}_{3}\right|>L S D$ so $H_{0}$ rejected. While in case III || $\bar{y}_{2}-\bar{y}_{3} \mid=8,87$ and LSD $=8,76$, consequently $\left|\bar{y}_{2}-\bar{y}_{3}\right|>L S D$ so $H_{0}$ rejected. It can be concluded $\mu_{1}=\mu_{2}>\mu_{3}$.
\end{abstract}

Keywords: Effectiveness, Team Assisted Individualization, Student Teams Achievement Divisions

\section{INTRODUCTION}

Education is one of the most important aspects for humans because human education can develop itself to manage the environment so that he can become a potential and qualified human being. A country can be said to be advanced in the field of education if the quality of education is guaranteed good. Education according to Law No.20 of 2003 "Education is a conscious and planned effort to create a learning atmosphere and learning process so that students actively develop their potential to have spiritual strength, self-control, personality, intelligence, noble character, and skills which are needed by himself, society, nation, and state ". In general, a teacher has a very important role in the education process, especially in the learning process, because the learning process is the core of the overall education process. The learning process is an activity of communication between teachers and students. Good communication between teacher and student will have an impact on student learning outcomes. Students will be motivated to learn even when learning mathematics which is generally feared by students. According to Suherman, Erman et al. (2003: 55-56), School mathematics is mathematics taught in schools, namely mathematics taught in Elementary Education (Elementary and Junior High School) and Secondary Education (High School and Vocational School). The function of mathematics subjects is as a tool, mindset, and science. One that influences students' mathematics learning outcomes is that which is related to the learning method used by the teacher in the learning process. According to Uno, Hamzah (2010: 139) Student learning outcomes in mathematics subjects are the result of activities from learning mathematics in the form of knowledge as a result of the treatment or learning done by students. In other words, the learning outcomes of mathematics are what students get from the learning process of 
mathematics. Applying the right learning model in the process of learning mathematics can create a pleasant and interesting atmosphere for students. One interesting learning model and increasing the interactive intensity of students is the cooperative learning model.

Cooperative learning is one example of a learning model used in a learning process to achieve the objectives of learning activities. Cooperative learning can be done by dividing students into small groups to carry out activities together. Not only that, but the cooperative learning model also requires student collaboration and interdependence in the structure of tasks, goals, and rewards. The role of the teacher in cooperative learning as a facilitator, moderator, organizer, and mediator. Various kinds of cooperative learning models can be used by teachers, including the type of Team Assisted Individualization (TAI) and type Student Teams Achievement Divisions (STAD). The TAI type of cooperative learning model is one type of cooperative learning that prioritizes group success, therefore smart students are responsible for helping weak students in their groups to achieve success. If in a group there is one member who is still not correct in completing individual assignments given by the teacher and has not understood the concept of the material being discussed, the other group members are responsible for helping the student in solving the problem and at the same time explaining until the student understands the concept, so that eventually all group members have the same level of understanding. Thus a conducive learning activity atmosphere will be created where smart students can develop their abilities, while weak students will be helped in understanding the concepts being studied. So that the results of learning mathematics become better. According to Slavin (2005: 195-200) the steps of TAI learning are: 1) Teams. Students are divided into teams of 4-5 people. 2) Placement Test. Students are given preprogram tests in the field of mathematical operations at the beginning of the program. 3) Material. Study the subject matter to be discussed. 4) Group Learning. Students do group learning with their colleagues in a team. 5) Scores and Recognition. The work of students at the score at the end of the teaching, and each team that meets the criteria as a super team must get an award from the teacher. 6) Teaching groups. The teacher teaches each group about the material that has been discussed. 7) Fact Test. Ask students to work on tests to prove their true abilities. The STAD type cooperative learning model is a Cooperative Learning approach that emphasizes activities and interactions among students to motivate each other and help each other in mastering subject matter to achieve maximum achievement. With this model, it is expected that students can freely express their opinions, try to solve the problems given by the teacher by discussing and exchanging opinions with their group mates. Thus, students will be easier to receive material so that they can improve student learning outcomes, especially in mathematics. STAD consists of five main components namely class presentations, teams, quizzes, individual progress scores, team recognition. According to Slavin, E, Robert (2005: 143-146) there are five main elements, namely: 1) Class Presentation. Students will realize that they must give full attention during class presentations. 2) Team. The team becomes a very important thing in STAD because in a group there must be a cooperative work between students to achieve the expected academic abilities. 3) Quiz. After about one or two periods after the teacher gives the presentation and about one or two periods of team practice, students will work on individual quizzes. 4) Individual Progress Score. Individual progress scores are useful for motivating to work hard to get better results compared to previous results. Individual progress scores are calculated based on the base score and test score. 5) Team Recognition. The team will get an award if their average score reaches certain criteria. For example, awarding Good Team, Excellent Team, and Perfect Team award.

Following the results of interviews with one of the eighth-grade mathematics subject teachers, that the learning model used still uses conventional learning models, namely learning models that are still teacher-centered (teacher-centered), so that students in math lessons feel bored, being passive and student dependence on teachers is still high. Besides, said by the mathematics teacher in question many students still have difficulty learning mathematics and only rely on their friends when given questions, students do not want to try first because students already feel they cannot. Students assume that mathematics is a difficult lesson because it is full of calculations and formulas. Besides, based on observations in class VIII SMP Negeri 1 Kretek Bantul, during the learning process, many students were less actively involved in 
learning, most students did other activities outside of learning activities such as engrossed in talking with their peers regardless of the teacher who was teaching and disturbing another friend. Students' displeasure with these mathematics subjects will have an impact on student learning outcomes. This is evident from the results of even UTS scores that many students still get scores below the KKM, which is 72 .

From the existing problems, researchers are interested in taking the title Effectiveness of the use of the cooperative learning model type TAI and STAD type on the mathematics learning outcomes of class VIII SMP Negeri 1 Kretek Bantul 2015/2016 Academic Year. The formulation of the problem in this study are:

1. Are there differences in the learning outcomes of mathematics in learning using the TAI type learning model, the STAD type learning model and the conventional learning model in class VIII SMP Negeri 1 Kretek Bantul 2015/2016 Academic Year?

2. Is the TAI type learning model more effective than the STAD type learning model and conventional learning model towards the mathematics learning outcomes of class VIII SMP Negeri 1 Kretek Bantul 2015/2016 Academic Year?

The objectives of this study are:

1. To find out the differences in mathematics learning outcomes in learning using the TAI type learning model, the STAD type learning model and conventional learning models in class VIII SMP Negeri 1 Kretek Bantul 2015/2016 Academic Year.

2. To find out more effective learning models between TAI type learning models, STAD type learning models, and conventional learning models on student mathematics learning outcomes in Even Semester of class VIII SMP Negeri 1 Kretek Bantul 2015/2016 Academic Year.

\section{METHODS}

This type of research is experimental research in the form of True Experimental Design with the type of Posttest-Only Control Design (Sugiyono, 2012: 112). In this study using three classes, namely experimental class I, experimental class II and control class. In the experimental class, 1 learning was carried out using the TAI model and in the experimental class 2 learning was done using the STAD model and the control class was conducted using conventional learning models. The population in this study were all eighth-grade students of class VIII SMP Negeri 1 Kretek Bantul in Even Semester 2015/2016 Academic Year totaling 161 students. While the samples in this study were class VIII B as the experimental class 1 and VIII D as the experimental class 2 and class VIII C as the control class, the sampling technique used was Random Sampling. The test used is the analysis prerequisite test by the normality test of the Chi-Quadratic formula and the homogeneity test of the Bartlett test formula. The research hypothesis test uses ANOVA with the F test. The test after ANOVA is used the LSD (Least Significance Different) test to find out the learning model that has the most significant effect on mathematics learning outcomes.

\section{RESULTS AND DISCUSSION}

\section{Early Ability}

\section{a. Test the Normality of Students' Early Capabilities}

The summary results of the normal ability normality test can be seen in Table 1 .

Table 1. Summary of Initial Ability Normality Test Results

\begin{tabular}{|c|c|c|c|c|c|}
\hline Class & $\boldsymbol{X}_{\text {count }}^{2}$ & $\boldsymbol{X}_{\text {table }}^{2}$ & Significant Level & df(k- 1) & Info \\
\hline Experiment 1 & 0,4496 & 7,815 & $5 \%$ & 3 & Normal \\
\hline Experiment 2 & 3,7141 & 5,991 & $5 \%$ & 2 & Normal \\
\hline Conventional & 0,9607 & 5,991 & $5 \%$ & 2 & Normal \\
\hline
\end{tabular}


b. Test Homogeneity of Early Student Ability

The summary of the results of the initial homogeneity test can be seen in Table 2 .

Table 2. Summary of Initial Ability Homogeneity Test Results

\begin{tabular}{|c|c|c|c|l|}
\hline $\boldsymbol{X}_{\text {count }}^{\mathbf{2}}$ & $\boldsymbol{X}_{\text {table }}^{\mathbf{2}}$ & $\begin{array}{c}\text { Significant } \\
\text { Level }\end{array}$ & $\begin{array}{c}\mathbf{d f} \\
(\mathbf{k}-\mathbf{1})\end{array}$ & Information \\
\hline 1,75483 & 5,991 & $5 \%$ & 2 & Homogeneous \\
\hline
\end{tabular}

c. Average Initial Test Hypothesis

The summary of the results of the hypothesis test on the average initial capability can be seen in Table 3.

Table 3. Initial Ability Anava Summary

\begin{tabular}{|c|c|c|c|c|}
\hline $\begin{array}{c}\text { Source Of } \\
\text { Variance }\end{array}$ & Sum Of Squares & $\begin{array}{c}\text { Df (Degree } \\
\text { Of Freedom) }\end{array}$ & $\begin{array}{c}\text { Mean } \\
\text { Squared }\end{array}$ & \multirow{2}{*}{$\boldsymbol{F}_{\text {count }}$} \\
\hline Treatment & 1740,698 & 2 & 870,349 & \multirow{2}{*}{0,273} \\
\cline { 1 - 4 } Error & 18796,292 & 79 & 237,928 & \multirow{2}{*}{} \\
\hline Total & 20536,99 & 81 & & \\
\hline
\end{tabular}

From the table shows $F_{\text {count }}>F_{\text {table }}$ then $H_{0}$ be accepted. So that it can be said that there is no difference in the value of the initial ability of experimental class 1 , experiment 2 , and the control class in students of class VIII SMP Negeri 1 Kretek Bantul in even semester 2015/2016 Academic Year.

\section{Student Mathematics Learning Outcomes}

a. Normality test

The summary of the results of the normality of learning outcomes can be seen in Table 4 .

Table 4. Summary of the Normality Test Results of Mathematics Learning Outcomes

\begin{tabular}{|c|c|c|c|c|c|}
\hline Class & $\boldsymbol{X}_{\text {count }}^{\mathbf{2}}$ & $\boldsymbol{X}_{\text {table }}^{\mathbf{2}}$ & $\begin{array}{c}\text { Significant } \\
\text { Level }\end{array}$ & $\begin{array}{c}\mathbf{d f} \\
(\mathbf{k - 1 )}\end{array}$ & Information \\
\hline Experiment 1 & 6,8718 & 7,815 & $5 \%$ & 3 & Normal \\
\hline Experiment 2 & 0,102 & 5,991 & $5 \%$ & 2 & Normal \\
\hline Conventional & 2,5139 & 5,991 & $5 \%$ & 2 & Normal \\
\hline
\end{tabular}

b. Homogeneity Test

The summary of the results of the homogeneity of learning outcomes can be seen in Table 5 .

Table 5. Summary of Normality Test Results Mathematics Learning Outcomes Test

\begin{tabular}{|c|c|c|c|c|}
\hline$X_{\text {count }}^{\mathbf{2}}$ & $\boldsymbol{X}_{\text {table }}^{\mathbf{2}}$ & $\begin{array}{c}\text { Significant } \\
\text { Level }\end{array}$ & $\begin{array}{c}\mathbf{d f} \\
(\mathbf{k}-\mathbf{1})\end{array}$ & Information \\
\hline 1,47106 & 5,991 & $5 \%$ & 2 & Homogeneous \\
\hline
\end{tabular}

c. Hypothesis testing

The summary results of the test results of the learning outcomes hypothesis can be seen in Table 6.

Table 6. Summary of Anava Learning Outcomes

\begin{tabular}{|c|c|c|c|c|c|}
\hline $\begin{array}{c}\text { Source Of } \\
\text { Variance }\end{array}$ & $\begin{array}{c}\text { Sum Of } \\
\text { Squares }\end{array}$ & $\begin{array}{c}\text { Df (Degree } \\
\text { Of Freedom) }\end{array}$ & $\begin{array}{c}\text { Mean } \\
\text { Squared }\end{array}$ & $\boldsymbol{F}_{\text {count }}$ & $\boldsymbol{F}_{\text {table }}$ \\
\hline Treatment & 4866,930933 & 2 & 2515,011982 & \multirow{2}{*}{9,47837017} & \multirow{2}{*}{3,1246666667} \\
\hline Error & 21289,6667 & 79 & 265,342241 & & \\
\hline Total & 16156,5976 & 81 & & & \\
\hline
\end{tabular}

Table 6 shows the results $F_{\text {count }}>F_{\text {table }}$, then $\mathrm{H}_{0}$ rejected. So that it can be said that there are differences in mathematics learning outcomes between students who use the TAI learning model, 
the STAD model and conventional models in class VIII SMP Negeri 1 Kretek Bantul 2015/2016 Academic Year. Because there are differences between the three learning models, it is necessary to do an average test after ANOVA. The test after ANOVA was conducted to find out which learning model had the most significant influence on students' mathematics learning outcomes. The test after ANOVA used was LSD (Least Significance Different) test. The summary of the calculation results of the LSD test can be seen in Table 7.

Tabel 7. Summary of LSD Test Results

\begin{tabular}{|c|c|c|c|c|c|c|}
\hline Case & Comparison & LSD & $\left|\bar{y}_{i}-\bar{y}_{j}\right|$ & Result & $\overline{\boldsymbol{y}}$ & Conclusion \\
\hline Case I & $\mu_{1} v s \mu_{2}$ & 8,84 & 8,3 & $H_{0}$ accepted & 84,67 & \multirow{3}{*}{$\mu_{1}=\mu_{2}>\mu_{3}$} \\
\hline Case II & $\mu_{1} v s \mu_{3}$ & 8,76 & 17,17 & $H_{0}$ rejected & 76,37 & \\
\hline Case III & $\mu_{2} v s \mu_{3}$ & 8,76 & 8,87 & $H_{0}$ rejected & 67,5 & \\
\hline
\end{tabular}

Based on the Table, it can be seen in Case I because $\left|\bar{y}_{1}-\bar{y}_{2}\right|=8,3$ and LSD $=8,84$, as a result $\left|\bar{y}_{1}-\bar{y}_{2}\right|<L S D$ so $H_{0}$ accepted means $\mu_{1}=\mu_{2}$, which means that the TAI learning model is as effective as the STAD model.

In Case II $\left|\bar{y}_{1}-\bar{y}_{3}\right|=17,17$ and LSD $=8,6$, as a result $\left|\bar{y}_{1}-\bar{y}_{3}\right|>L S D$ so $H_{0}$ is rejected. because $\bar{y}_{1}=84,67$ and $\bar{y}_{3}=67,5$, as a result $\bar{y}_{1}>\bar{y}_{3}$ means $\mu_{1}>\mu_{3}$ meaning that the TAI model is more effective than the conventional model.

Whereas in case III $\left|\bar{y}_{2}-\bar{y}_{3}\right|=8,87$ and LSD $=8,76$, as a result $\left|\bar{y}_{2}-\bar{y}_{3}\right|>L S D$ so $H_{0}$ rejected. Because $\bar{y}_{2}=76,37$ and $\bar{y}_{3}=67,5$ as a result $\bar{y}_{2}>\bar{y}_{3}$ means $\mu_{2}>\mu_{3}$, which means that the STAD model is more effective than conventional models. So, the conclusion $\mu_{1}=\mu_{2}>$ $\mu_{3}$, it means that the TAI learning model is as effective as the STAD learning model, while the TAI learning model and the STAD learning model are more effective than conventional learning models for the mathematics learning outcomes of class VIII SMP Negeri 1 Kretek Bantul School 2015/2016 academic year.

\section{Discussion of Research Results}

Based on the results of the above data analysis, it can be concluded that mathematics learning using the Team Assisted Individualization (TAI) model is as effective as mathematics learning using the Student Teams Achievement Divisions (STAD) model, but mathematics learning using Team Assisted Individualization (TAI) models or Student Teams Achievement Divisions (STAD) results are more effective than learning using conventional models. This can be seen from the results of the LSD test at a significance level of $5 \%$ and the degree of freedom $(\mathrm{df})=79$, namely in case I $\left|\bar{y}_{1}-\bar{y}_{2}\right|=8,3<L S D=8,84$ then $H_{0}$ accepted. In Case II $\left|\bar{y}_{1}-\bar{y}_{3}\right|=17,17>$ $L S D=8,76$ then $H_{0}$ rejected. Whereas in case III $\left|\bar{y}_{2}-\bar{y}_{3}\right|=8,87>L S D=8,76$ then $H_{0}$ rejected, so $\mu_{1}=\mu_{2}>\mu_{3}$.

The TAI learning model is as effective as the STAD model because in the TAI and STAD models when learning in the classroom most students have a sense of responsibility in doing the task. Also, students actively ask if students still do not understand the material provided. At the end of the lesson, there was also a quiz that made students focus on understanding the subject matter and students were also enthusiastic in learning mathematics because there was an award. So that it makes the process of teaching and learning activities run smoothly and the results of students' mathematics learning become better.

Whereas in conventional learning models that tend to be teacher-centered, students are still less active in the learning process. When asked the students were only silent and if given the practice questions there were still many students who could not work because the students did not pay attention when the teacher delivered the material and was only engrossed in chatting with other students. In the end, it will affect the process of learning mathematics. 


\section{CONCLUSION}

1. There are differences in mathematics learning outcomes between students who are treated by using the cooperative learning model Team Assisted Individualization (TAI) type, Student Teams Achievement Divisions (STAD) and conventional learning models in class VIII SMP Negeri 1 Kretek Bantul Yogyakarta Academic Year 2015 / 2016.

2. Learning that uses the Team Assisted Individualization (TAI) model is as effective as learning using the Student Teams Achievement Divisions (STAD) model, but learning that uses the Team Assisted Individualization (TAI) or Student Teams Achievement Divisions (STAD) model results are more effective than in learning that uses conventional models of mathematics learning outcomes in class VIII SMP Negeri 1 Kretek Bantul Yogyakarta Academic Year 2015/2016.

\section{REFERENCES}

Slavin Robert,E. 2005.Cooperative Learning ,Teori, Riset dan Praktik. Bandung : Nusa Media.

Sugiyono. 2012. Metode Penelitian Pendidikan Pendekatan Kuantitatif, kualitatif, dan R\&D. Bandung : Alfabeta.

Suherman, Erman dkk. 2003. Strategi Pembelajaran Matematika Kontemporer. Bandung: Universitas Pendidikan Indonesia.

Uno, Hamzah.2010. Model Pembelajaran Menciptakan Proses Belajar Mengajar yang Kreatif dan Efektif. Jakarta : Bumi Aksara. 